\title{
Bureaucratic Reform to the improvement of public services Challenges for Indonesia
}

\author{
Yusriadi* \\ Sekolah Tinggi Sekolah Tinggi llmu Hukum (STIH) Pengayoman, Indonesia
}

Diterima Februari;2018; Disetujui April 2018 Dipublikasikan Juni 2018

\begin{abstract}
Many factors can affect the performance of the government bureaucracy, including the absence of meritocracy (using the best talent) caused, for example, the recruitment process which does not target all segments of society, elections and the progress of civil servants are not based on the capacity, knowledge and skills, in fair competition and open. This study addressed the issue of government bureaucracy in Indonesia, which is multidimensional and protracted as a vicious circle, and discusses how improved public service for good governance can create and utilize to get out of the vicious circle and deterioration in innovative ways. This study used a qualitative approach. Based on data collection techniques, data collection techniques used in this research is the study of the literature on the theory of Reinventing Government, which is considered as the main theory. Results from this study, to solve complex problems required comprehensive strategy consisting of three areas, namely, political leadership, harmonization of public policy (including rules and regulation), and free from corruption
\end{abstract}

Keywords: Bureaucratic reform, Public service, Governance, Corruption, Developing country, Indonesia

How to Cite : Yusriadi, (2018). Bureaucratic Reform to the improvement of public services Challenges for Indonesia 6 (1): 15-29

$\begin{array}{ll}{ }^{*} \text { Corresponding author: } & \text { P-ISSN-2549-9165 } \\ \text { E-mail: yusriadi@yahoo.com } & \text { e-ISSN -2580-2011 }\end{array}$ 


\section{Introduction}

Why the quality of public services provided by the Indonesian government bureaucracy is remain poor? Many factors can affect the performance of the government bureaucracy, including the absence of meritocracy (using the best talent) caused, for example, the recruitment process which does not target all segments of society, elections and the progress of civil servants are not based on the capacity, knowledge and skills, in fair competition and open. In general, the placement of civil servants is not based on competency and performance, but rather on political considerations and patrimonialism. The situation is exacerbated by a competitive compensation system that is unfair and uncompetitive compensation system.

Corruption in Indonesia is a phenomenon of chronic and widespread that good governance, erodes the rule of law, hindering efforts to economic growth, increasing social inequality, and distorts the nation's competitiveness in the global economy. Politicians, for example, be used to searching for a political campaign fund from bureaucrats in exchange for protection and from the large corporations in exchange for offering business opportunities such as government contracts and procurement, mining, logging and plantation licenses. Transparency International report released in 2010 showed that in Indonesia's Corruption Perception lndex $(\mathrm{CPl})$ ranks 100 of 182 countries, with a score of 3.0 out of
10 (very clean) to 0 (highly corrupt) (www.thejakartaglobe.com). Scores of 5.0 or below is regarded as a corrupt country. Moreover, there is indications bureaucracies' lack of integrity. The value of public sector integrity in Indonesia is still low and not too far from the standards of integrity minimum set by the KPK (Corruption Eradication Commission), which is 6.0 (on a scale of 1 being the lowest for 10 as the highest), and did not mention the extensive practice manipulation of public financial accountability.

Combating corruption is very difficult because the public administration system of rules-driven that focuses on formal correctness rather than substantive truth. Most practice rent-seeking can not be prosecuted for what they are doing is taking advantage of loopholes existing legal system. Formally, the seeker lease obtained personal financial benefit by manipulating the social or political environment, even though they do not necessarily violate any law (KPK, 2010).

In LAKIP (Accountability Report Government Performance) there is a tendency to only report things that are good, that is, those who in line with the rules and regulations, even when it is not in accordance with the institution's mission, as well as to conceal all information that is deemed not appropriate for inclusion into "good report". The LAKIP bias because it is a self-evaluation report. Moreover, this practice has become complicated because 
many rules and regulations that is not compatible with each other. In addition, the problem could worsen because there is no policy evaluation and evaluation of programs / projects in the public administration system of Indonesia; therefore, there is no adequate feedback to decision makers and public policy.

That's why we can not learn from our experiences and tend to repeat the same mistakes again. It seems that corruption is a vicious circle because of the lack of change caused by the status quo (Kasim, 2008). In general, the administration and public policy practice in Indonesia is still influenced by the classic paradigm that relies on a hierarchical top-down approach. Activities of government bureaucracy should start from the policy, planning and implementation of policies, including public services. But there is no evaluation, and hence, there is no feedback to the policy and decision-makers (Hughes, 2003).

Dynamic capabilities the organization generated by people capable, thus forming the agile process for policy formulation and evaluation (Anwar, 2010).

Indonesia's experience can be explained by the theory of prismatic society by Fred W. Riggs (1964). Although there is no freedom of speech, civil culture has not developed accordingly. Public participation in the political process there has been no or very minimal. Political activity is dominated by the ruling elite subjective particularistic values and orientation consists of nepotism, ethnic considerations faith-based and other forms of narrow political orientation. This condition causes decreased attention paid to the public interest such as nationalism and the public interest. Linear mindset remains the dominant force in government bureaucracy, and therefore, supporters are working hard to maintain the status quo. Currently, the Indonesian government bureaucracy is still very much based on obsolete yet rigid rules and regulations that are not responsive to the needs of citizens to public services efficiently (World Bank, 2003).

Indonesian bureaucracy problem lies in the human factor and also, the system must be changed through bureaucratic reform. Reforms or bureaucratic reinvention is about replacing the bureaucratic system or self-renewing system (Osborne and Plastrik, 1998). The reinvention of bureaucracy performed with institutional reordering of public services, simplification of procedures, the application of minimum service standards, increased use of information and communication technologies in service management, and the implementation of quality management in the public service, including the handling of public complaints management.

\section{Reinventing Government}

The implementation of regional autonomy based on Law No. 22 in 1999 will have serious implications for the region. At least, local governments should be able to 
explore its potential to increase revenue as the main capital to economic development in the region. To that end, a system of regional bureaucracy that is efficient, transparent and accountable should be a work reference. On the other hand, regional autonomy is not solely concerned how the area is able to creatively develop the potential of the area to increase the region PAD, as often we hear these days, but more than that, local autonomy should be seen in a broader perspective (Afan, 1995).

To meet the challenges emerging as a consequence of the implementation of regional autonomy, we need, as often discussed by several authors, who have the entrepreneurial spirit bureaucracy. This is because decentralization, both in the administrative context and the political context can never be implemented effectively if local government officials failed to develop adequate capacity to manage the development process. In this context, the reinventing government is significant and finding the right moment.

Reinventing government itself by Osborne and Plastrik in Banishing bureaucracy is interpreted as follows (Osborne and Plastrik, 1992).

The fundamental transformation of public systems and organizations to create dramatic increases in their effectiveness, efficiency, adaptability, and capacity to innovate, this transformation is accomplished by changing their purpose, incentives, accountability, power structure, and culture.

In the context, reinventing interpreted as a reinvention of bureaucracy to a system based on self-employment, ie creating organizations and the public to get used to updating the system, which in a sustainable manner, improve the quality without having gained impetus from outside.

Thus, reinventing means creating a public sector that has the urge from within to fix commonly called the "updating the system back on its own". The reinventing government made ready to face the challenges might not be anticipated. In addition, reinventing not only improve the effectiveness of the current government but also be able to build organizations to be able to improve the effectiveness in the future at a time of changing an organizational environment.

Furthermore, in connection with the globalization of markets, in order to encourage the market in order to remain efficient, the bureaucracy requires entrepreneurial qualities. There are seven competencies must be owned by entrepreneurial bureaucracy, namely (Moeljarto, 2001): (1) Sensitive and responsive to new opportunities and challenges in the market; (2) Not glued to the regular activities related to the instrumental function of the bureaucracy, but must be able to break through creative and innovative thinking; (3). Having a futuristic insight and systematic; (4). Has 
the ability to anticipate, calculate, and pose a risk; (5) Observant of the potential sources and new opportunities; (6). Has the ability to combine resources into resource mix to have higher productivity; (7). Has the ability to optimize the available resources, to shift the source of low-productivity activities towards high-productivity activities.

Discussion on the character of the bureaucracy has entrepreneurial spirit can be found in a book written by David Osborne and Ted Gaebler titled Reinventing Government: How the Entrepreneurial Spirit is Transforming the Public Sector. This book is essentially a criticism of the federal government bureaucracy in the United States are no longer efficient in managing public services. As expressions Osborne and Gaebler, we live in an era of change is amazing, in a global market is highly competitive, in an information society where people can use the information as fast as their leader, living in an economy based on knowledge where knowledge workers do not want in control by command and demanding autonomy, in an era of market where consumers are accustomed to high quality and plenty of choices (Osborne and Gaebler, 1992).

Thus, the emergence of the concept of bureaucracy entrepreneurial can not be separated from global developments regarding two key dimensions, namely economic globalization, in terms of urging towards economic integration into the global market, and fundamental changes as a catalyst of globalization, the revolution in communications technology and the lower cost transport. The second factor mentioned this has fundamentally changed the global political and economic structure (Susan, 2000).

Furthermore, Osborne and Gaebler stated that environmental changes take place, demanding the institution is very flexible and able to adapt quickly. Environmental changes require institutions capable of providing high-quality goods and services deliver results more from each dollar provided by each customer. The change also requires institutions responsive to customers by offering a wide selection of services to not standardize; with much guided by persuasion and encouragement rather than by command; provide an understanding of the meaning and control, even ownership to their workers. Finally, change requires the institution authorizes the citizens than merely serving them (Osborne and Gaebler, 1992).

The concept of entrepreneurial bureaucracy is a critique of the Weberian bureaucracy is very hierarchical. Although at first, the bureaucracy is a system of institutional work is expected to be a tool to serve the interests of society with effective and efficient, in fact quite the opposite. Bureaucracy tends to slow, hierarchical, inefficient, and only a waste of government budgets.

Therefore, with a lot of learning from this century marketing expert, Peter 
Drucker, they begin to give an idea about the importance of having a soul entrepreneur bureaucracy. Supported by research conducted in several US states, Osborne and Gaebler formulating ten principles of bureaucracy have entrepreneurial spirit, namely (Osborne and Gaebler, 1992): (1) Government Catalyst: Directing Rather than Pedaling; (2) Government-owned Peoples: Giving Authority Rather than Serving; (3) Competitive Government: Injecting Competition into Service Delivery; (4). Government-driven Mission: Organization Change is driven by regulation; (5) Results oriented Government: Finance Results Compared with input; (6) Customer orientated Government: Meet Customer Needs not bureaucracy; (7) Entrepreneurial Government: Produce Compared to Spending; (8) Anticipatory Governance: Preventing than Treat; (9) Government Decentralization; (10) Market-oriented Government: Boosting Change Through Market.

With concise language, Osborne and Gaebler sum up the ten principles of entrepreneurial bureaucracy in paragraphs summarized as follows;

...most entrepreneurial governments promote competition between service providers. They empower citizens by pushing control out of the bureaucracy, into the community. They measure the performance of their agencies, focusing not inputs but on outcomes. They are driven by their goals-their missionnot by their rules and regulations. They redefine their clients as customers and offer them choices-between schools, between training programs, between housing options. They prevent problems before they emerge, rather than simply offering services afterward. They put their energies into earning money, not simply spending it. They decentralize authority, embracing participatory management. They prefer market mechanism to bureaucratic mechanism. And they focus not simply on providing public services, but on catalizing all sector-public, private, and voluntary-into action to solve their community's problems.

\section{Research Methods}

This study used a qualitative approach. Based on data collection techniques, data collection techniques used in this research is the study of the literature on the theory of Reinventing Government, which is considered as the main theory.

\section{Result and Discussion}

How concept entrepreneurial bureaucratic can be applied in Indonesia, especially in the context of regional autonomy? So that the purpose of the implementation of decentralization and regional autonomy can be achieve by either. 
To address this problem, there are five strategies that can be used to make a fundamental change in promoting effective and efficient bureaucracy, or the ability to adjust or adaptability, and capacity for updating the system and public organizations (Osborne and Plastrik, 1992).

First, the core strategy, this strategy determines the system and public organizations. If organizations do not have clear goals or have many goals or contradictory, then an organization cannot achieve high performance. In other words, a public organization able to work effectively if has a specific purpose.

Therefore, it is important for leaders of public organizations to establish specific organizational goals. Determination of the vision and mission of the organization has an important role in complementing the purpose of public organizations. It is intended that employees have clear direction and grip. Beyond that, this strategy is primarily concerned with efforts to improve the direction (steering).

Second, the consequences strategy, this strategy determines the incentives that built into the public system. Bureaucracy gives employees a strong incentive to follow the rules and simultaneously comply. In the old bureaucratic model, employees earn the same salary regardless of what they produce. However, in order reinventing government, as revealed by Osborne and Plastrik, changing incentives is important by creating consequences for performance. If necessary public organizations placed in the business world, and make the organization depends on its customers to earn income. However, if this is not feasible, it needs to make a contract or agreement in order to create competition between public and private organizations (competition between public organizations). This is because the market and competition creates incentives are much stronger so that public organizations are encouraged to provide greater performance improvement. Incentives and competition can have diverse forms, such as medical benefits, a raise, or a reward for public organizations that have higher performance.

Third, customer strategy, this strategy focuses on accountability. Unlike the old bureaucracy, the bureaucracy a new model, the responsibility of implementing public bureaucracy should be placed in the community, or in this context be considered as a customer. Thus, the responsibility is no longer placed on bureaucratic officials on it, but rather to a broader public. Models such as these are expected to increase pressure on public organizations to improve the performance or management of organizational resources. Furthermore, by giving the responsibility to the public or consumers, will be able to create information, namely about customer satisfaction on the result and certain government services.

In other words, handover of responsibility to consumers means that public organizations should have a goal to be 
achieved, namely to increase consumer satisfaction.

Fourth, the control strategy, this strategy determines the location of the decision-making power given, in the old bureaucratic system, most of the power to stay on top of the hierarchy, in other words, the highest authority to make decisions at the peak of the hierarchy. The development of increasingly complex modern bureaucracy has made the organization becomes ineffective. This is because the decision-making process must go through a long hierarchy so as to make decision-making processes tend to be slow, and if it is imposed, and if it is imposed, it will impact the bureaucracy barrier (Sarundajang, 1999).

In the end, overall, bureaucracy system performance in handling problems and provide services to the public will be slow because subordinates are not given enough room to take the initiative in solving problems. Furthermore, in the old bureaucratic model, managers have limited choices, and the flexibility they are squeezed by the provisions of a detailed budget, individual regulation, system revenues (procurement systems), auditing practices, and so on. Employees they hardly have the power to make decisions.

As a result, government organizations more respond to new orders compared to the changed circumstances or needs of customers. Therefore, it is important to decentralize decision-making to officials and employees of bureaucracy beneath as this will encourage a sense of responsibility among employees of the bureaucracy, in a broad context to encourage community involvement in the process of policy implementation.

Fifth, the culture strategy, this strategy determines the organizational culture of the public regarding the values, norms, attitudes, and expectations of the employees. This culture makes it stronger by the goals of the organization, incentive, responsibility system, and the power structure of the organization. In other words, changing the objectives, incentives, accountability system and power structure of the organization will change the culture.

\section{Some Constraints}

Now, the problem is happening, how the government is able to implement the five strategies in an effort to reinventing government, and creating a bureaucracy that has an entrepreneurial spirit. This question deserves expressed due to the successful application of a theoretical concept will be greatly determined by the social, economic, political, and cultural surrounding. It must be remembered that the book written by Osborne and Gaebler referring to cases in the US federal state where community structures are economically more affluent and politically more democratic. Moreover, in the USA state bureaucracy characteristic although it also refers to the bureaucratic model of Weber, but in contrast to the characteristics of the bureaucracy in Indonesia. Moreover, in the American bureaucracy is not infected by the 
disease of corruption and nepotism culture a very strong.

One of the factors that constrain the implementation of reinventing government in Indonesia is related to the characteristics of bureaucracy in Indonesia. Bureaucracy in Indonesia, by some authors have characteristics that are quite similar to the bureaucracy in most Third World countries (Kuntjoro, 1980) a very strong feel of paternalistic (Dwiyanto, 2002) and very naive perspective of the people they are supposed to serve.

Many cases in the Third country World, bureaucracy would be a major barrier to the development process that is being implemented. Observations have been carried out regarding the development in the Third World, the result is a failure of development in Third World countries it appears from the State apparatus (Kuntjoro, 1980). Bureaucracy in the Third World is a political machine that is not neutral, and will not be neutral. Of course, this is very different from the bureaucracies in the advanced industrial countries. As revealed by Max Weber, the bureaucratic machinery in industrialized countries developed very formal and legalistic. In other words, the state apparatus that acts as bureaucracy in industrialized countries are very loyal to the constitution and convention.

As the apparatus, the bureaucracy will not take action in favor of the ruling government in a state where the government is experiencing a crisis of confidence, both of which are reflected in the legislature and through a growing public opinion (Soemarsono, 2001).

In Indonesia, a growing bureaucratic model does not seem too far away with the bureaucratic model in these Third World countries. In the reform period, the bureaucracies have become a party political machinery of government, into a strong organization, and nearly tend autonomous from community control. Consequently, because of the bureaucracy into a powerful political organization, movement dominates almost all public life, this phenomenon as a political community of bureaucracy.

This bureaucratic political society characterized by at least three things, namely: First, the dominant political institution is the bureaucratic apparatus. Secondly, other political institutions such as parliaments, political parties, and interest groups are weak, and not able to control the bureaucracy. Third, the masses outside the bureaucracy, both politically and economically as a result of the weak role of political parties, but it strengthen the role of the bureaucracy (D. Jackson \& Lucian Pye, 1978).

In a bureaucratic political community, as characterized by bureaucratic reform, important decisions are formulated in the bureaucracy, the military corps, and civil administration. Groups outside the bureaucracy, as a consequence of strong organizations, such as the charismatic leader, political parties, interest groups, and the mass movement does not have influence in the decision-making process at the national level. 
(Girling, 1981). In short, the national policy is created in a small circle of influential elite, and the policy is usually aimed at responding to the values and interests of military leaders and high-level bureaucrats (Jackson, 1978).

In political society, mass mobilization that involves most of the people are only allowed by the government in the process of policy implementation than the decisionmaking at the national level. Mobilization was usually confined to the local level, and organized by the elite in a way upward through the traditional power and patronclient relationship (Soemarsono, 2001). Furthermore, the nature of bureaucracy is characterized patron-client relationship gave birth to the type of bureaucratic patrimonial, namely a bureaucracy where existing relationships, both internally and externally is the relationship between patron and clients that are very personal and distinctive (Kuntjoro, 1980).

For this purpose, can be done in two ways, namely; first, through the reaffirmation of the commitment of the political elite to reform public bureaucracy more accountable and favor the interests of the people; and secondly, by using the democratic wave that is now flowing (Regulski and W. Kocan, 1994).

The concerns above, a different strategy are needed for the government bureaucracy in Indonesia, which is considered necessary to combine the practice of public management to private management. According Gidden (Cassell, 1996) in a structuration theory emphasizes the integration of structure (structural principles of organization, resource rule sets, stretching across time and space) and agency (the power of action individual).

The Indonesian government has launched a reform of the bureaucracy that aims to develop clean, efficient, effective and productive bureaucracy. These reforms are designed to create a transparent bureaucracy that is serving the people and accountable to the public. The purpose of bureaucratic reform is to improve the performance of government bureaucracy Acceleration program of the Ministry of State Apparatus Empowerment and Bureaucratic Reform (MENPAN \& RB). The question is, will this bureaucratic reform efforts can improve the performance of government bureaucracy in providing public services and citizen empowerment? If we compare the essence of the problems faced by the bureaucracy with the scope of bureaucratic reform efforts, it is clear that the effort is not adequate because it focuses primarily on implementing existing rules and regulations.

Efforts unfortunately still reflect what the government wants to do, base on existing law, and focusing on the implementation of existing policy. In other words, it is not about a change of mindset or contents harmonization of policies, rules or regulations. This is ironic, given the fact that the main problem of the government bureaucracy in Indonesia is caused by disharmony public policy, rules and 
regulations. For example, disharmony between Law 32 of 2004 on Regional Government and Re-Act No. 17 of 2003 ReFinance State, as well as the one found among the nine laws and hundreds of regulations on land use management are at odds with each other illustrates this situation well (KPK 2006).

Government bureaucracy condition becomes more complicated because it follows the practice; (1) There is a tendency for people to rent seeking, bribery, or giving gratuities to government officials to obtain preferential treatment in public services and in particular, to obtain concessions for the exploitation of deposits of scarce natural resources such as mining concessions and permits oil palm plantations; (2) The collusion between government officials and businesses leading to markup practices in government procurement, and give satisfaction as a kickback to officials; (3) Political intervention in the recruitment of civil servants as well as in government procurement and contracts (spoils system); (4) Corruption in law enforcement agencies, namely the police, lawyers, courts and tax authorities (www.economist.com).

Given the above phenomenon, it seems that the problems faced by the Indonesian government bureaucracy is not linear, but rather a systemic, complex and dynamic. There are many variables and interconnections between institutions and individuals involved in this issue, including cultural aspects such as community values, beliefs, and norms. With regard to the behavior of Indonesian government officials is high, the Economist writes that "some people are driven by a sense of guilt, others with shame. Then there is Indonesia, which are rarely well controlled" (www.economist.com).

While the US (as well as Japan, Korea, India and European countries) officials retreated quickly enough during a corruption scandal, the leader of Indonesia, known as a long track record they refuse to resign their positions regardless of how serious the charges against them, and how much public pressure, It is a challenge Indonesia to be overcome, namely to find an appropriate form of administrative reform and national development strategies which maximize the opportunity for dialogue between all stakeholders representing all segments of society.

The above issues need to be addressed by the entire people of Indonesia and in particular the Government. This should be done through appropriate public policies that can serve as leverage to get rid of the vicious cycle, and to be able to empower government officials and citizens. Furthermore, we need to answer the following questions ( 1 ) What is the strategy of bureaucratic reform should be chosen?; (2) Who is responsible for leading the bureaucratic reform, and from the point where we should start? To solve the problem of complex and dynamic we need a more comprehensive strategy that includes three main areas, namely political leadership, 
harmonization of public policy (including rules and regulations), and the anticorruption movement.

First, we need transformational leadership in order to lead a radical change. Patrimonialism, nepotism, rule-driven orientation, and rents a very common practice in Indonesia without distinguishing among ethnic and religious backgrounds. Values and beliefs clearly incompatible with a democratic system of government, therefore, it is difficult to initiate radical change through democratic mechanisms that exist because there is no civil culture.

The transactional leadership style tends to reinforce the values and beliefs of the above. On the other hand, reform of the bureaucracy or administrative reform is a top-down approach; Therefore, to be chaired by officials: President of Indonesia. To initiate a change, reform of the bureaucracy needs to be strong, visionary and transformational leadership to motivate people and create synergies in national development (Farazmand, 2002).

And it must have the capacity to lead the anti-corruption movement and eliminate the phenomenon of high-cost economy in order to create a government that is efficient and reliable. Leadership must be demonstrated strong personal integrity and commitment. He must make a difficult decision and a dilemma to overcome various political, economic and social. Transformational and charismatic leadership can play a more important role in the effort to create a cultural change values and paradigms that are more conducive to the good governance leading dynamic (Wart and Dicke, 2008).

Secondly, harmonization of policies, laws, rules and regulations that exist, almost all laws, rules, and regulations that exist in disharmony with each other because of the lack of coordination and synchronization between the various public institutions in policy-making and in the implementation process. For example, in the agrarian sector, there are nine 285 laws and rules and regulations that do not fit with each other. ldeally, public policy must be aligned with each other in order to become an effective leverage in national development initiatives (Osborne and Plastrik, 1998). Strong, visionary and transformational leadership needed to lead the effort to bring about a change in the legal system that will serve as the basis of bureaucratic reform. Indonesia must be free from the vicious circle trap protracted problems of corruption and inefficiency.

Although Indonesia has several comparative advantages of natural and human resources, but in the long term, their own is far from enough to survive in the global competition. Thus, national development programs should be focused on the development of industrial clusters that can compete in the global economy (Fukuyama, 2004).

Third, the anti-corruption should include preventive and curative measures. 
Law enforcement may simply not be enough to prevent corruption due to disharmony laws, rules and regulations. The weak legal system is part of the problem. Ideally, reform of the legal system must be carried out before the reform of the bureaucracy. We must consider that the Indonesian legal system also adopts the principle of presumption of innocence in anti-corruption, money laundering and tax domain, to reduce opportunities for corruption occurs.

Good governance enables the government bureaucracy to perform quality and efficient public services. That there LAKIP (Accountability Report Government Performance) can not be considered as an objective measure because it is a kind of selfevaluation made by heads of government agencies, and there is a tendency to report only the good things and hide all the irregularities as the practice markup in government purchasing/procurement. Citizens and society, in general, should participate in the control of the government bureaucracy because they are the main stakeholders, to whom the government bureaucracy should be responsible for.

Government bureaucracy must be strengthened not only by the planning and implementation of activities but also with the evaluation of the results of their activities to the external evaluators and professionals. Three strategies can create strong organizational ability of the government bureaucracy that functions as the leverage that allows people to get rid of the vicious circle of corruption and underdevelopment, and to create a clean government and agile process, the bureaucratic government must have the ability to dynamically and can participate in the process cycle thinking ahead, thinking again and thinking across. In order to remain relevant to the needs of society, national development programs must be dynamic, systemic and sustainable (Neo and Chen, 2007).

The reinventing framework of good governance can be described as strong political leadership and a visionary can play an important role in improving the performance of government bureaucracy. Three other strategies discussed above can create conditions conducive to the reform of the bureaucracy, especially in enhancing the dynamic capacity in the public service and citizen empowerment. Testament government bureaucracy always relevant to the changing needs of the community if it always adapts to the surrounding environment in innovative ways.

\section{Conclusion}

In a rapidly changing world, there is no guarantee that Indonesia's economic growth will be sustained in the future. The situation will be even worse if the government bureaucracy is now part of the problem. This paper discusses the current issues of government bureaucracy in Indonesia are multi-dimensional in nature and have long been a vicious circle. 
Efforts to reform the government bureaucracy in Indonesia will never be successful if it is done in a linear mindset that does not address the root problem. This paper has described how reinventing government approach to good governance can create leverage to get rid of the vicious circle in an innovative way.

\section{DAFTAR PUSTAKA}

Anwar, Rozan. 2010. Development of Dynamic Capabilities of Education Service Policy Processes in Jembrana, Bali. Jurnal llmu Administrasi dan Organisasi, Bisnis \& Birokrasi, Vol. 17, No. 3 (November).

Cassell, Philip. 1996. The Giddens Reader,

California-USA: Stanford University press

Corruption Everywhere. 2011. www.economist.com. 4 September.

Dwiyanto, Agus, 2002, Reformasi Birokasi Publik di Indonesia, Yogyakarta: Pusat Studi Kependudukan dan Kebijakan, Universitas Gadjah Mada.

Farazmand, Ali. 2002. Administrative Reform in Developing Nations. Westport, Conn: Praeger.

Fukuyama, Fransis. 2004. State Building: Governance and World Order in the Twenty-First Century. London: Profile Books.

Gaffar, Afan, 1995, "Otonomi Daerah dalam Negara Kesatuan", Prisma 4, April 1995. Girling, John L. S., 1981, The Bureaucratic Polity in Modernizing Societies, Differences, and Prospect in The Asean
Region, Singapore: Institute of Southeast Asian Studies.

Hughes, Owen E. 2003. Public Management \& Administration: An Introduction. New York: Palgrave Macmillan.

Jackson, Karl D., 1978, "Bureaucratic Polity: A Theoretical Framework for Analysis of Power and Communication in Indonesia", dalam Karld D. Jackson and Lucian Pye, (eds.), Political Power and Communication in Indonesia, Berkeley and Los Angeles: University of California Press.

Kasim, Azhar. 2008. Peluang dan Tantangan dalam Pembangunan Indonesia: Permasalahan dan Upaya Mengatasinya. JIANA, Vol. 8, No. 2 (Juli).

Kuntjoro-Jakti, Dorodjatun, 1980, "Birokrasi di Dunia Ketiga: Alat Rakyat, Alat Penguasa, atau Penguasa?", Prisma, 10 Oktober 1980.

KPK, Directorate of Research and Development. 2010. Indonesia Public Sector Integrity 2009: Corruption Facts in Public Service.

KPK. 2006. Identification of Gaps between Laws/ Regulations of the Republic of Indonesia and the United Nations Convention Against Corruption.

Neo, Boon Siong and Geraldine Chen. 2007. Dynamic Governance: Embedding Culture, Capabilities and Change in Singapore. Singapore: World Scientific.

Osborne, David and Peter Plastrik. 1998. Banishing Bureaucracy: The Five 
Strategies for Reinventing Government.

New York: A Plume Book.

1992, Banishing Bureaucracy, New

York: Addison-Wesley Publishing

Company, Inc.

and Ted Gaebler, 1992. Reinventing

Government: How the Entrepreneurial

Spirit is Transforming the Public Sector,

New York: Penguin Books Ltd.

Regulski, Jerzy and W. Kocan, 1994, "From

Communism Towards Democracy: Local

Government Reform in Poland", dalam

Robert J. Bennet, 1994, (ed.), Local

Government and Market

Decentralization: Experiences in

Industrialized, Developing, and Former

Eastern Bloc Countries, Tokyo: United

Nations University.

Show To Shame. 2011. www.economist.com. 4

September.

Soni Soemarsono, 2001, "Peranan Akuntansi dalam Sektor Publik pada Era Otonomi Daerah bagi Pemerintahan Daerah dan Masyarakat Menuju Terciptanya Good Governance" , Makalah disampaikan pada Diskusi Panel sehari di Istana Ballroom Sari Pacific, Kamis, 22 Maret 2001.

Strange, Susan, 2000, "States, Firms, and Diplomacy", dalam Jeffrey A. Frieden and David A. Lake, (eds.), International Political Economy: Perspective on Global Power and Wealth, Fourth Edition, Boston: Bedford/St. Martin's.
The truth about corruption in Indonesia. 2011. www.thejakartaglobe.com. 4 September.

Tjokrowinoto, Moeljarto, 2001, "Pengembangan Sumber Daya Manusia Birokrasi: Kemelut antara Negara, Masyarakat Sipil, dan Pasar", dalam Saiful Arif, (ed.), Birokrasi dalam Polemik, Yogyakarta: Pustaka Pelajar.

Wart, Van and Dicke, Lisa. 2008.

Administrative Leadership in The Public Sector. London: ASPA.

World Bank: East Asia Poverty and Economic Management Unit. Combating Corruption in Indonesia: Enhancing Accountability for Development. 2003. www.siteresources.worldbank.org. $\quad 15$ Agustus. 